\title{
A coal-sulfur model for Sydney Coalfield (Upper Carboniferous), Nova Scotia, Canada
}

\author{
Erwin L. Zodrow \\ Department of Earth Sciences, University College of Cape Breton, Sydney, Nova Scotia B1P 6L2, Canada
}

Date Received April 4, 1991

Date Accepted September 16, 1991

\begin{abstract}
Methods of modern factor analysis are applied to a set of 31 variables (metals, sulfur and ash) of coal data, with focus on explaining the sulfur variance in coal for the formulation of a coal-sulfur model. The derived five hypothetical factors which are fitted to the conceptual coal-sulfur model are inferred to represent general sedimentary/ geochemical processes, except for one for which there is no available identity and no corresponding process in the conceptual model. The fluvial sedimentary influx and the pyrite-forming factors are the most influential in explaining the variation of sulfur in the coal, where the latter factors are linked with sulfur supplied from recycled sulfate solution. The factor interpretation is consistent with independent results that identify clay minerals and pyrite as the dominating coal mineralogy in the Sydney Coalfield.
\end{abstract}

Des données relatives au charbon et réparties selon un ensemble de 31 variables (métaux, soufre et cendres) furent soumises à diverses méthodes modernes d'analyse factorielle, et ce, dans l'optique d'expliquer la variance du soufre au sein du charbon en vue de la formulation d'un modèle mettant en relation le charbon et le soufre. Les cinq facteurs hypothétiques qui en sont dérivés et qui sont intégrés à ce modèle conceptuel, semblent traduire l'influence de processus sédimentaires ou géochimiques communs, à l'exception d'un seul pour lequel il n'existe ni identité disponible, ni processus correspondant à l'intérieur du modèle conceptuel. L'apport sédimentaire fluvial et les facteurs contribuant à la formation de pyrite se révèlent prépondérants pour expliquer la présence de soufre au sein du charbon, où ces facteurs sont reliés au soufre provenant du recyclage des sulfates en solution. Cette interprétation est en accord avec des résultats indépendants qui identifient la pyrite et des argiles comme les minéraux principaux au sein du charbon provenant du bassin houillier de Sydney.

[Traduit par le journal]

\section{INTRODUCTION}

Factor analysis (Table 1) is a statistical technique based on involved matrix computation and on complex hypotheses (Harman, 1965). A methodological requirement is that the isolated hypothetical factors comprising the factor model are fitted to an $\grave{a}$ priori developed model (the conceptual coalsulfur model, Kendall, 1965, p. 37), to prevent as much as possible that the subsequent interpretation is not merely a tautological transformation of the original variables (Mulaik, 1972 , p. 363). This approach to data analysis furthermore commands justification of both the geological and the factoranalytical hypotheses for a meaningful interpretation. The onus, therefore, rests on the factor analyst, as factor analysis presupposes subjective parameters which do not lead to an interpretation that is scientifically unique. Factor analysis is most effectively used when studying the underlying structure of experimental data matrices with many variables, as in the present study.

With the caveat, R-mode factor analysis, which focuses on correlation between pairs of variables, is performed on the data. The objective '... is intended more for exploratory purposes than for confirming detailed statistics - so factor analysis can be used as a tool in developing theories in the geological sciences' (in litt., H.H. Harman, 1974). Specifically, variance sources of the sulfur variable are examined to explain them in terms of broad geological processes.

\section{Previous Work}

Data of a stratigraphic survey on bulk geochemistry of coal seams from the Sydney Coalfield were published by Zodrow (1987). Involved in the survey were 17 whole coal channel samples that were taken from 10 successive coals, for a total of 137 individual coal samples. For each sample, 42 elements and their concentration levels and ash content were determined by appropriate analytical methods. The data from that survey, excepting $\mathrm{Au}, \mathrm{Pd}, \mathrm{Pt}, \mathrm{Ga}, \mathrm{Nb}, \mathrm{Y}, \mathrm{Cd}, \mathrm{Cs}, \mathrm{B}, \mathrm{Sm}$ and $W$, are used in the present study for a total of 30 elements and ash content (Table 2). For details on stratigraphy and thickness of the coal seams sampled, sampling methodology, sample preparation, ashing procedure, instrumental methods, and detection limits, the reader is referred to Zodrow (1987). Sample locations are shown in Figure 1. 
Table 1. Assumptions: principal components and common factors.

\begin{tabular}{|c|c|c|}
\hline PRINCIPAL COMPONENTS & \multicolumn{2}{|l|}{ COMMON FACTORS } \\
\hline $\begin{array}{l}\text { Communality }\left(h^{2}\right)=\text { unity } \\
\text { No allowance is made for error variance. }\end{array}$ & \multicolumn{2}{|c|}{$\begin{array}{l}\mathrm{h}^{2} \text { is estimated; variance is open to interpretation, and it is conceded } \\
\text { that it is not known whether all variables in the analysis are relevant. }\end{array}$} \\
\hline $\begin{array}{l}\text { No assumption about structure is } \\
\text { necessary. }\end{array}$ & \multicolumn{2}{|c|}{ A priori assumption about factor structure. } \\
\hline $\begin{array}{l}\text { Principal components: exact mathemati- } \\
\text { cal transformation of the variables. }\end{array}$ & \multicolumn{2}{|c|}{ Common factors are no longer exact transformation of the variables. } \\
\hline \multicolumn{3}{|c|}{ Decreasing factor contribution } \\
\hline & \multicolumn{2}{|c|}{$\begin{array}{l}\text { Principle of parsimony: fewer factors than variables. } \\
\text { Factor characteristics: all general factors are bipolar, after the first } \\
\text { one. }\end{array}$} \\
\hline \multicolumn{3}{|c|}{$\begin{array}{l}\text { Stop factoring: when eigenvalues } \\
\text { become less than unity. }\end{array}$} \\
\hline \multicolumn{3}{|c|}{ ROTATION } \\
\hline Orthogonal & Orthogonal & Oblique \\
\hline Component axes are not correlated. & Factors are assumed not correlated. & Factors are assumed correlated. \\
\hline Solution matrices: & Solutio & natrices: \\
\hline Component matrix. & Factor matrix. & Factor matrix. \\
\hline Rotated component matrix. & Rotated factor matrix. & $\begin{array}{l}\text { Pattern and structure matrices. } \\
\text { Factor correlation matrix. }\end{array}$ \\
\hline
\end{tabular}

References: Nie et al. (1975); Harman (1965). 
Table 2. Sample mean and standard deviation of the 31 variables, Sydney Coalfield, Nova Scotia.

Lithophile elements

$\begin{array}{lc}\text { Al wt.\% (0.01) } & 0.71 \pm 1.00 \\ \text { Ba ppm (10) } & 40 \pm 59 \\ \text { Be ppm (10) } & 4 \pm 5 \\ \text { Ca wt.\%(0.01) } & 0.15 \pm 0.20 \\ \text { K wt.\%(0.01) } & 0.09 \pm 0.18 \\ \text { Mg wt.\%(0.01) } & 0.04 \pm 0.05 \\ \text { Mn ppm (2) } & 105 \pm 233 \\ \text { Na wt.\% (0.01) } & 0.03 \pm 0.02 \\ \text { Rb ppm (2) } & 9 \pm 11 \\ \text { Sc ppm (0.1) \& } & 1.5 \pm 2.2 \\ \text { Si wt.\% (0.01) } & 1.01 \pm 1.44 \\ \text { Sr ppm (10) } & 29 \pm 53 \\ \text { Th ppm (0.1) \& } & 1.2 \pm 2.1 \\ \text { Ti wt.\% (0.01) } & 0.03 \pm 0.5 \\ \text { U ppm (0.01) } & 0.51 \pm 0.99 \\ \text { V ppm (0.8) } & 14.4 \pm 22.1\end{array}$

Chalcophile elements

$\begin{array}{lc}\text { Ag ppm (0.5) } & 0.3 \pm 0.5 \\ \text { As ppm (0.5) \& } & 106.3 \pm 120.6 \\ \text { Cr ppm (2) \& } & 9 \pm 12 \\ \text { Cu ppm (0.5) } & 19 \pm 21 \\ \text { Fe wt.\% (0.01) } & 3.42 \pm 3.28 \\ \text { Ge ppm (10) } & 7 \pm 10 \\ \text { Hg ppb (10) \& } & 137 \pm 113 \\ \text { Pb ppm (2) } & 43 \pm 86 \\ \text { S wt.\% \& } & 4.78 \pm 4.31 \\ \text { Sb ppm (0.1) \& } & 1.8 \pm 2.6 \\ \text { Se ppm (1) } & 3 \pm 6 \\ \text { Zn ppm (0.5) } & 78.5 \pm 214.5 \\ & \\ \text { Siderophile elements } & \\ \text { Co ppm (1) } & 5 \pm 10 \\ \text { Ni ppm (1) } & 12 \pm 22\end{array}$

Ash wt.\% 9.7 \pm 8.9

\& Determined on the whole-coal sample; the remaining, done on ashed coal, were recalculated to whole-coal equivalent by the formula: recalculated value = value in ashed coal/(100/ash content).

Bracketed value is the detection limit (Zodrow, 1987, Table 1).

\section{Sydney Coalfield: the Conceptual Coal-Sulfur MODEL}

Coals in the Sydney Coalfield were deposited in a deltaic flood-plain environment (Hacquebard and Donaldson, 1969) and range in age from Westphalian $\mathrm{C}$ to Cantabrian (Zodrow and Cleal, 1985 and references therein). As detailed by Birk (1990, Table 2), the pyrite- and kaolinite-dominated coal mineralogy is very complex and facies related. Total sulfur in the unoxidized coals of Sydney Coalfield is derived from three sources (Beaton, 1986): (1) sulfatic (identified as mainly crystalline gypsum), (2) organic (collectively for sulfur bonded to organic molecules - Casagrande and Siefert, 1977; Spiro et al., 1984), and (3) sulfidic (derived from sulfide minerals but chiefly from pyrite). Both Beaton (1986 - see Table 2), and Birk (1990) are emphatic about non-secondary sulfatic sulfur being a minor proportion of the total coal sulfur.

Sydney's coals show total sulfur that ranges from $0.41 \% \mathrm{~S}$ to $21.05 \%$ S (Fig. 2). Close to $50 \%$ of the sulfur samples are near or below the $2 \% \mathrm{~S}$ mark and the associate coal samples are termed (1) low sulfur coals, and those with over $2 \% \mathrm{~S}$ (2) high sulfur coals. The low-sulfur coals are generally found in seams distal to channel deposits, or in coals situated in the more central part of the coalfield (Newman, 1935; Haites, 1951; Hawley, 1955). Low sulfur content is also observed distal to shale partings within a coal seam (Table 3). Newman
(1935) showed that the total sulfur content (1.1\%S - 2.3\%S) of samples from parts of the Phalen Seam, which is low in sulfur content is mainly organic, with little or no pyrite. Lowsulfur coal samples are represented in the study (Table 4) from the Harbour (Lingan Colliery) and the Phalen (\#26 Colliery) seams and generally show a much more homogeneous sulfur distribution, in comparison with the high-sulfur coals which show top-bottom enrichment. It is further shown (Zodrow, 1987, Table 2) that trace metal distribution in the channel sample with low sulfur from the Phalen Seam is much more homogeneous compared to that of the high-sulfur coal samples.

High-sulfur coals are characterized by sulfur reaching a level of $21 \%$ S. They tend to originate from parts of seams proximal to sandstone layers with associated overlying paleochannels (Newman, 1935; Haites, 1951; Forgeron et al., 1986). A detailed study of the vertical distribution of sulfurform (Table 3) of a high-sulfur coal of the Harbour Seam a few kilometers from the western edge of the Coalfield (Fig. 1, location $\mathrm{W}$ ) shows that with lower pyritic content the organic sulfur proportion increases (total sulfur tends to be dominated by increasing amounts of organic sulfur), and that on average pyrite contributes nearly $90 \%$ of the sulfur. The highsulfur coal samples are also characterized by pronounced vertical sulfur trends, as exemplified by the channel samples from the Point Aconi, Lloyd Cove, and the Harbour (location 


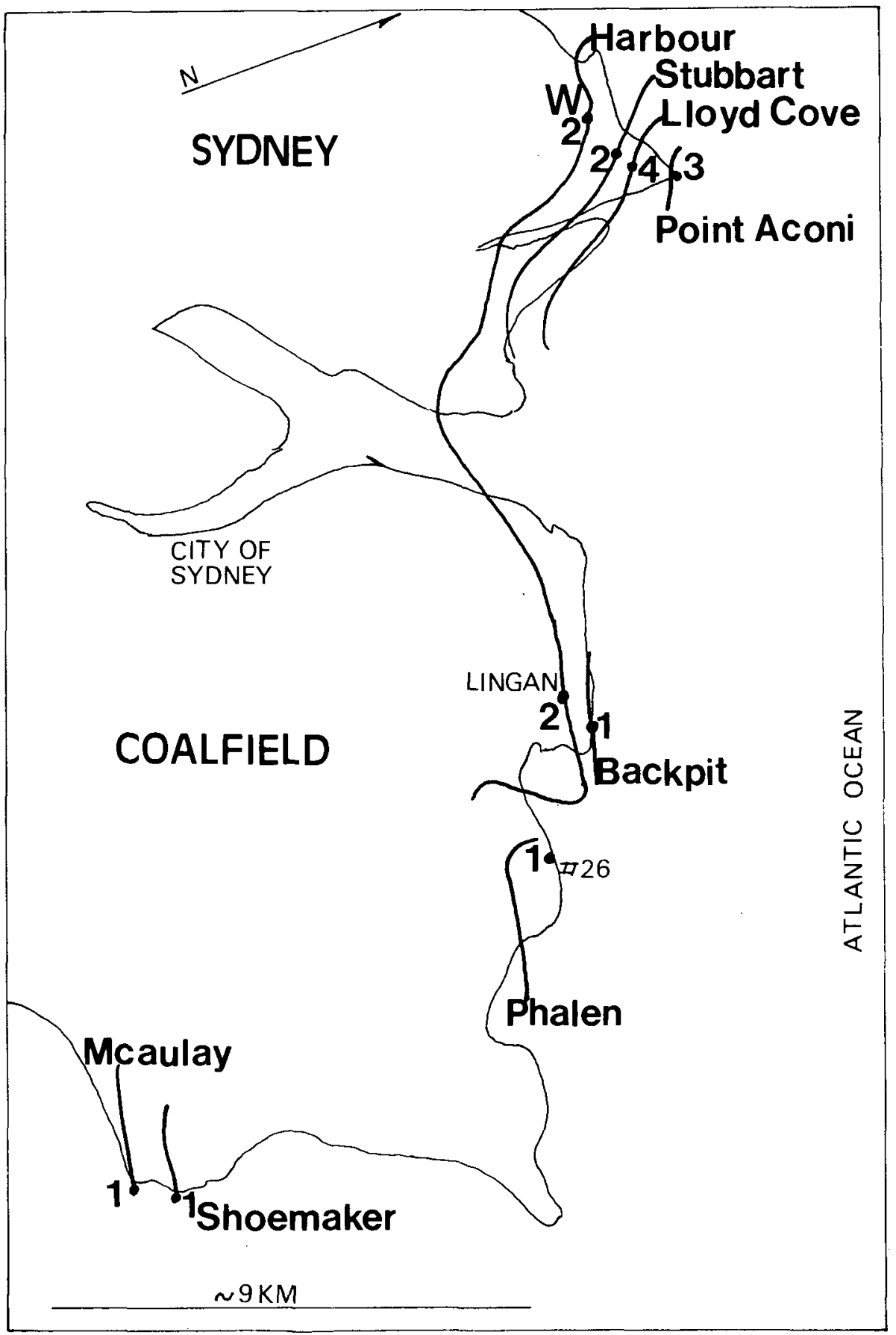

Fig. 1. Location map of the channel samples, Sydney Coalfield, Nova Scotia, Canada. Numbers refer to the number of channel samples taken from the coal seams, including the Harbour Seam at the open pit mine of the NovaCoal Company (W), Lingan (Lingan Colliery), and \#26 (the Phalen Seam in \#26 Colliery). Included in the number of channel samples shown from the Lloyd Cove Seam are two that are from the overrider, the Unnamed Seam. The Point Aconi Seam is the youngest and the McAulay Seam the oldest.

W) seams (Table 4). Indeed, the top-bottom enrichment trend is duplicated for most other geochemical variables from the high-sulfur coal samples (Zodrow, 1987).

For this paper, Birk's (1990, Table 1) interpretation of the multistage paragenetic history of pyrite in the Sydney Coalfield is relevant: syngenesis (early and late diagenetic), and epigenesis (cleat mineralization). Other classifications exist (Spears, 1987, p. 178-180) but are not appropriate.
Field and scanning electron microscopic studies by the author identified galena, the phase association of sphaleritechalcopyrite-pyrrhotite-pyrite, and marcasite (Zodrow and McCandlish, 1978) in some coal samples. The galena (sample 991GF-235) has only been found in the roof cleats of the Lloyd Cove overrider seam (Fig. 1, location W), where it occurs without being visibly associated with other sulfide phases. Evidently, the sulfide phases contribute a minor 


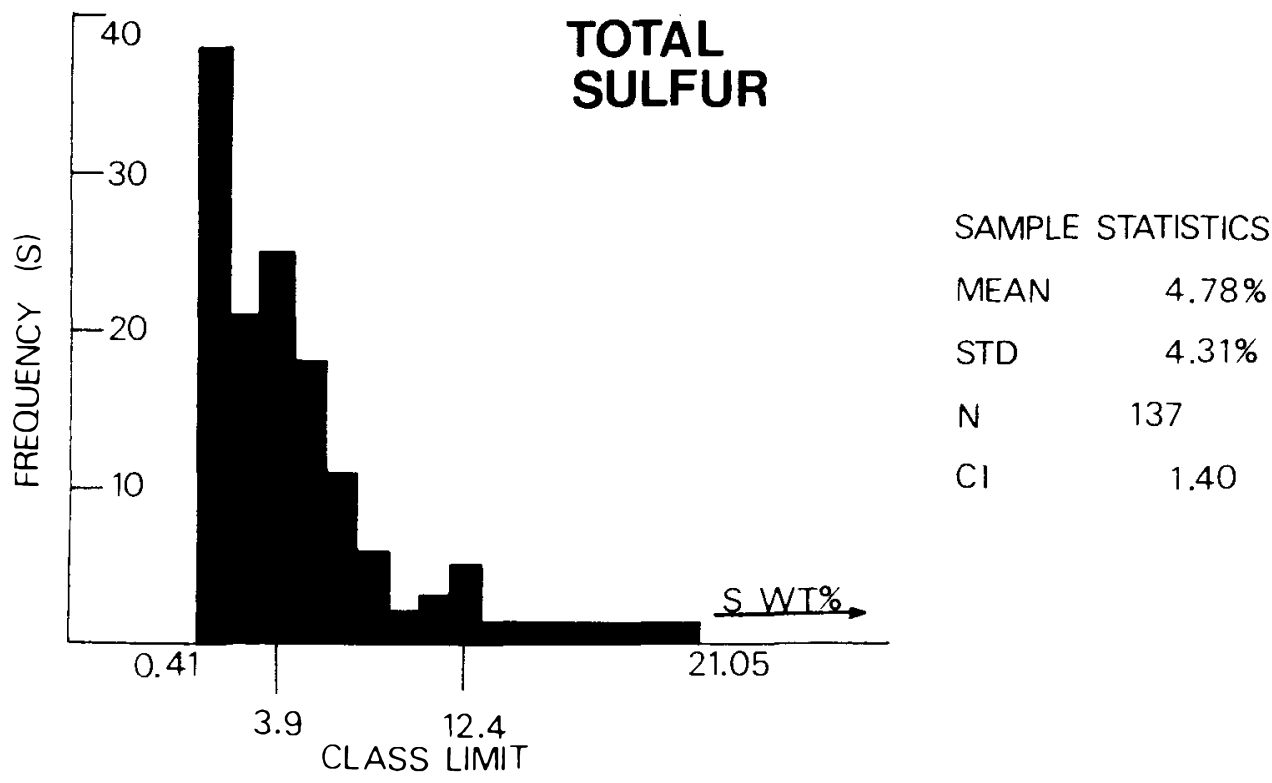

Fig. 2. Frequency distribution of the sulfur variable. STD - standard deviation, $\mathrm{N}$ - sample size, and CI - class interval.

Table 3. Ash and sulfur-form data (in weight percent) in the channel sample of the sulfur-rich Harbour Seam, Sydney Coalfield, Nova Scotia, Canada.

\begin{tabular}{|c|c|c|c|c|c|}
\hline \multirow{2}{*}{$\begin{array}{l}\text { Depth } \\
\text { cm }\end{array}$} & \multirow[t]{2}{*}{ Ash } & \multicolumn{4}{|c|}{ Sulfur-form } \\
\hline & & organic & sulfatic & pyritic & Total \\
\hline 4.5 & 51.7 & 2.04 & 0.84 & 15.00 & 17.88 \\
\hline 8.0 & 47.2 & 0.96 & 0.91 & 14.68 & 16.55 \\
\hline 15.5 & 17.1 & 1.86 & 0.42 & 9.52 & 11.18 \\
\hline 24.1 & 11.1 & 0.63 & 0.11 & 5.37 & 6.11 \\
\hline 32.3 & 11.7 & 1.39 & 0.25 & 5.75 & 7.40 \\
\hline 40.4 & 13.8 & 0.82 & 0.18 & 6.42 & 7.42 \\
\hline 48.5 & 18.5 & 0.00 & 0.23 & 12.63 & 12.86 \\
\hline 56.7 & 9.9 & 0.80 & 0.08 & 3.10 & 3.98 \\
\hline 65.3 & 10.2 & 0.00 & 0.14 & 8.35 & 8.49 \\
\hline \multirow[t]{2}{*}{67.1} & 45.9 & 1.18 & 0.57 & 15.45 & 17.20 \\
\hline & \multicolumn{4}{|c|}{ shale split: $22-23 \mathrm{~cm}$ thick } & \\
\hline 91.6 & 24.0 & 0.64 & 0.18 & 4.96 & 5.78 \\
\hline 95.6 & 12.1 & 1.60 & 0.18 & 6.74 & 8.52 \\
\hline 103.4 & 8.5 & 0.87 & 0.16 & 5.48 & 6.51 \\
\hline 111.5 & 7.2 & 0.47 & 0.11 & 4.29 & 4.87 \\
\hline 120.2 & 5.4 & 0.76 & 0.13 & 2.66 & 3.55 \\
\hline 128.7 & 11.3 & 1.11 & 0.15 & 6.97 & 8.23 \\
\hline 137.1 & 7.2 & 0.94 & 0.31 & 3.46 & 4.71 \\
\hline 145.3 & 8.1 & 0.65 & 0.15 & 5.12 & 5.92 \\
\hline 153.9 & 8.8 & 0.36 & 0.15 & 5.06 & 5.57 \\
\hline Mean & 17.3 & 0.90 & 0.28 & 7.42 & 8.42 \\
\hline Std & 4.5 & 0.55 & 0.24 & 4.10 & 4.39 \\
\hline
\end{tabular}

From Beaton (1986). Method of analysis by ASTM standards.

Location is at $\mathrm{W}$ in Figure 1. 
Table 4. Sulfur (S) and ash (weight percent) for 6 whole-coal channel samples from 4 coal seams, Sydney Coalfield, Nova Scotia.

\begin{tabular}{|c|c|c|c|c|c|c|c|c|c|c|c|}
\hline \multicolumn{4}{|c|}{ Point Aconi* } & \multicolumn{2}{|c|}{ Lloyd Cove } & \multicolumn{4}{|c|}{ Harbour Seam } & \multicolumn{2}{|c|}{ Phalen Seam } \\
\hline \multirow{14}{*}{\begin{tabular}{c}
\multicolumn{1}{c}{$S$} \\
12.8 \\
3.9 \\
3.5 \\
2.9 \\
5.8 \\
10.7 \\
17.5
\end{tabular}} & \multirow{3}{*}{$\begin{array}{r}\text { ash } \\
20.2 \\
5.6\end{array}$} & \multirow{2}{*}{$\begin{array}{c}S \\
4.9\end{array}$} & \multirow{2}{*}{$\begin{array}{l}\text { ash } \\
7.1\end{array}$} & & ash & \multicolumn{2}{|c|}{ W } & \multicolumn{2}{|c|}{ Lingan } & \multirow{3}{*}{$\begin{array}{c}S \\
1.5 \\
2.0\end{array}$} & \multirow{3}{*}{$\begin{array}{l}\text { ash } \\
8.0 \\
8.4\end{array}$} \\
\hline & & & & & 12.3 & & & & 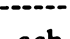 & & \\
\hline & & 3.5 & 5.9 & & 6.0 & $S$ & ash & $\mathbf{S}$ & ash & & \\
\hline & 3.4 & 4.7 & 8.8 & 3.9 & 4.7 & 7.3 & 40.3 & 0.5 & 1.5 & 1.7 & 6.9 \\
\hline & 2.3 & 2.8 & 6.0 & & 3.6 & 4.3 & 10.3 & 0.5 & 1.6 & 2.2 & 9.5 \\
\hline & 6.2 & 3.7 & 7.3 & & 5.4 & 3.5 & 5.9 & 0.5 & 1.7 & 1.1 & 7.2 \\
\hline & 14.8 & 11.7 & 15.7 & 5.1 & 6.6 & 4.8 & 6.7 & 0.6 & 5.9 & 1.4 & 7.9 \\
\hline & 21.8 & 21.1 & 39.0 & (11) & m) \& & shal & & 0.6 & 5.4 & 1.3 & 7.5 \\
\hline & (10 & n) \& & & & & & 10.9 & 0.7 & 3.2 & 0.8 & 10.5 \\
\hline & & & & & & & 5.8 & 1.1 & 5.1 & 1.1 & 2.5 \\
\hline & & & & & & & 5.8 & 1.1 & 6.1 & 1.3 & 4.4 \\
\hline & & & & & & 7.3 & 10.6 & 0.9 & 8.6 & 2.2 & 4.8 \\
\hline & & & & & & $(13$ & m) \& & 1.0 & 4.4 & 1.2 & 2.5 \\
\hline & & & & & & & & $(14$ & 1) \& & (1) & $\mathrm{cm}) \&$ \\
\hline
\end{tabular}

* Separated by a distance of 15 meters.

\& Approximate seam thickness.

W, at the western edge of the Sydney Coalfield (Fig. 1)

Lingan, Lingan Colliery (Fig. 1). Sampling length within a channel sample is approximately $15 \mathrm{~cm}$.

portion to the observed variance of sulfur in coal, compared with that of the pyrite contribution.

Data are available (Table 5) to support the assumption made in Table 2 regarding assignment of certain sample elements to the chalcophile group. Furthermore, Birk's (1990) and Beaton's (1986) observations on the presence of kaolinite, illite, and quartz on bedding planes of coal samples is evidence for $\mathrm{Al}, \mathrm{Si}, \mathrm{K}, \mathrm{Mg}$ and $\mathrm{Na}$ being lithophile elements and representatives of clastic detrital mineralogy (clays, sandstones) in the coals. However, clay and quartz may also be of diagenetic and epigenetic origins (Birk, 1990) and have been observed as cell fillings or as replacement in coal samples (Beaton, 1986).

A sulfur content as high as $21 \% \mathrm{~S}$ can hardly be expected from botanical sources alone in the coal-forming environment of the Sydney Coalfield (Casagrande, 1987). To attempt to account for the higher levels, two secondary enrichment suppliers merit consideration. One involves the evaporite deposit of the Windsor Group underlying and adjacent to the Sydney Basin as a supplier through the recycling of sulfaterich solutions, a hypothesis supported by stable sulfur isotopic data (Gibling et al., 1989). The second supplier relates to marine incursions themselves, but the palaezoological and geochemical data are not consistent in that regard. Reported were finds of agglutinated foraminifera (Trochammina, Miliammina, and Ammobaculites spp. - Thibaudeau, 1987), and fish remains (megalichthiid crossopterygian - Zodrow et al., 1989) that suggest marginal marine conditions. Data on boron geochemistry for the Sydney Coalfield show values that do not exceed $20 \mathrm{ppm}$ for the limestone in which the fish remains were found (Vasey and Zodrow, 1983), do not exceed $4 \mathrm{ppm} \mathrm{B}$ in a pyrite sample (Table 5), and from two coal seams do not exceed 20 ppm (Table 6). These B concentrations fall short of indicating marine influence, if a comparison can be made with 100 to $180 \mathrm{ppm} \mathrm{B} \mathrm{in} \mathrm{marine} \mathrm{shales}$ of Pennsylvanian age (Keith and Degens, 1959, Fig. 2).

From the compositional differences in the two pyritic samples (Table 5), particularly between the rare earth/actinide elements, no firm trace-elemental criteria can as yet be established for separating epi-from syngenetic pyrite and for distinguishing between pyrite from freshwater and marine facies (Keith and Degens, 1959, pp. 51-53).

As a working hypothesis, total sulfur variation is associated with four general sedimentary and geochemical processes, as summarized by the conceptual coal-sulfur model (Table 7). In factor methodology, the calculated oblique factors are now required to be fitted to the processes of the conceptual model.

\section{Assumptions for the Oblique Factor Model}

\section{The coal geochemical bulk sampling data}

The geochemical data consist of a matrix with the 137 samples as in the rows, and the 31 variables as in the columns. The variables represent selected geochemical attributes of the complex organic rock coal (Berry et al., 1983, p. 543), and the Sydney coals contain nearly all of the natural elements in the periodic table (Sandeman, 1979). In coal, certain metals may be partitioned between the organic phase as an organocomplex (organic affinity, see summary by Zubovic, 1966; Krejci-Graf, 1984) and the mineral phase (inorganic affinity, 
Table 5. Trace elements, $\mathrm{ppm}^{*}$, in fine-grained and cleat-coal pyrite concentrate samples, Sydney Coalfield, Nova Scotia.

Sample 977GF-732-2 Harbour Seam (fine-grained pyrite)

\begin{tabular}{rrrrrrrrrrrrrrrrr}
\hline $\mathrm{As}$ & $\mathrm{Au}$ & $\mathrm{B}$ & $\mathrm{Ba}$ & $\mathrm{Be}$ & $\mathrm{Br}$ & $\mathrm{Co}$ & $\mathrm{Cr}$ & $\mathrm{Hg}$ & $\mathrm{Cs}$ & $\mathrm{Cu}$ & $\mathrm{Ni}$ & $\mathrm{Pb}$ & $\mathrm{Sb}$ & $\mathrm{Se}$ & $\mathrm{Zn}$ & $\mathrm{Zr}$ \\
240 & $\mathrm{bd}$ & 4 & 120 & 1 & 4 & 3 & 32 & 3 & 3 & 15 & 80 & 70 & 5 & 12 & 65 & 130
\end{tabular}

Sample 977GF-177

Phalen Seam (cleat pyrite)

$\left.\begin{array}{rrrrrrrrrrrrrrrrr}\hline 1,500 & 48 & \text { bd } & 10 & \text { bd } & 1,000 & 20 & 7 & 8 & \text { bd } & 45 & 10 & 70 & \text { bd } & 88 & 25 & 40 \\ (1 & 2 & 0.5 & 1 & 1 & 0.5 & 0.1 & 0.5 & 10 & 0.2 & 5 & 5 & 2 & 0.1 & 0.5 & 5 & 1\end{array}\right)$

Rare earths and actinides:

\begin{tabular}{lrrrrrrrrrrr} 
& $\mathrm{Sc}^{* *}$ & $\mathrm{La}$ & $\mathrm{Ce}$ & $\mathrm{Nd}$ & $\mathrm{Sm}$ & $\mathrm{Eu}$ & $\mathrm{Tb}$ & $\mathrm{Yb}$ & $\mathrm{Lu}$ & $\mathrm{U}$ & $\mathrm{Th}$ \\
$\begin{array}{l}\text { Harbour } \\
\text { (fine-grained }\end{array}$ & 4.5 & 14 & 26 & 12 & 1.7 & 0.42 & 0.3 & 0.9 & 0.15 & 1.2 & 5.0 \\
$\begin{array}{l}\text { pyrite) } \\
\begin{array}{l}\text { Phalen } \\
\text { (cleat pyrite) }\end{array}\end{array}$ & 0.3 & 1.1 & 2 & $\mathrm{bd}$ & 0.1 & $\mathrm{bd}$ & $\mathrm{bd}$ & $\mathrm{bd}$ & $\mathrm{bd}$ & $\mathrm{bd}$ & $\mathrm{bd}$ \\
& $(0.01$ & 0.1 & 1 & 3 & 0.01 & 0.05 & 0.1 & 0.05 & 0.01 & 0.1 & $0.2)$ \\
\hline
\end{tabular}

\footnotetext{
*except Au which is in ppb.

bd $=$ below detection limit in brackets. Note that each pyrite sample is coal-contaminated, $4.2 \%$ and $7.7 \%$, respectively. Analysis by Activation Laboratories Limited, instrumental nuclear activation analysis, except $\mathrm{Cu}, \mathrm{Pb}, \mathrm{Zn}$ and $\mathrm{Zr}$ by plasma emission spectrometry and $\mathrm{B}$ by prompt gamma analysis.

**Correction: it is a transition element.
}

Spears, 1987). The assumption made in Table 2 that the metals determined in coal can be identified with Goldschmidt's geochemical groups is supported by pyrite data (Table 5) for the chalcophile elements, and by data obtained from the mineralogical coal study for the lithophile elements by Birk (1990). However, no hard data are available from the Sydney coals regarding metal partitioning as in organo-complexes.

\section{Frequency characteristics of the data}

Frequency analysis of all 31 variables shows that frequencies of concentration levels in reference to whole coal or equivalent are proportionately the most numerous when the concentration levels are lowest. With an increase of the levels, frequencies decrease rapidly so as to make a long right-hand tail (positive skewness as expected for geochemical variables). Hence, an unequal data spread about the means exist. Moreover, the frequency distribution of the variables can be subdivided into those that show only one frequency peak:

(1) Ag, As, Ba, Be? $\mathrm{Co}, \mathrm{Cr}, \mathrm{Ge}, \mathrm{Mo}, \mathrm{Na}, \mathrm{Ni}, \mathrm{Sc}, \mathrm{Se}, \mathrm{Th}, \mathrm{Ti}$ ? $\mathrm{U}, \mathrm{V}$, and $\mathrm{Zn}$ ?, and those that show more than one (number of peaks in bracket):

(2) $\mathrm{Al}(2), \mathrm{Ca}(3-4), \mathrm{Cu}(2), \mathrm{Fe}(3$ ?), $\mathrm{Hg}(3), \mathrm{K}(2), \mathrm{Mg}(2), \mathrm{Mn}(5-$ 6), $\mathrm{Pb}(2), \mathrm{Rb}(3), \mathrm{Si}(3), \mathrm{Sr}, \mathrm{S}(2)$, and $\mathrm{Ash}(2)$.

Of the latter category, Mn shows the most erratic behavior and Ash the least. To illustrate, the sulfur (Fig. 2) and the Fe frequency distributions (Fig. 3) are shown. These suggest an association of the peaks of the former with the sulfur populations: the first peak at $1.8 \% \mathrm{~S}$ could represent organic sulfur, the other peaks sulfur from pyrite and other sulfides. It is more difficult to associate the frequency peaks of the $\mathrm{Fe}$ variable with definite mineral phases, but presumably the area about the $2.62 \mathrm{Fe} \%$ and $8.32 \mathrm{Fe} \%$ represents the pyrite phase.

With only 137 available samples for each variable, it is difficult to decide on theoretical population models. For the purpose of this paper, which does not involve factor-analytical hypothesis testing, the data need not be normal (Harman, 1965 , p. 13, 382; chapter 17). The reader may assume lognormality for the variables and proceed to testing hypotheses on that basis. However, it may turn out that the transformed data set is not multinormal. Reyment (1971) proposed a test. 
Table 6. Boron content (ppm) in the ashed coal-channel samples from the Harbour and the Backpit Seams, Sydney Coalfield, Nova Scotia.

\begin{tabular}{|c|c|c|c|}
\hline \multicolumn{4}{|c|}{ Harbour Seam } \\
\hline \multicolumn{2}{|l|}{ W } & \multicolumn{2}{|c|}{ Lingan } \\
\hline B & ash\% & B & ash\% \\
\hline 10.0 & 17.4 & 6.8 & 2.9 \\
\hline 16.0 & 7.9 & 11.0 & 3.0 \\
\hline 18.0 & 11.1 & 7.2 & 1.5 \\
\hline shale & & 9.6 & 1.5 \\
\hline 17.0 & 6.8 & 11.0 & 2.5 \\
\hline 14.0 & 7.3 & 12.0 & 1.5 \\
\hline 16.0 & 3.9 & 10.0 & 2.6 \\
\hline \multirow{8}{*}{\multicolumn{2}{|c|}{$(95 \mathrm{~cm}) \&$}} & 12.0 & 1.8 \\
\hline & & 14.0 & 3.6 \\
\hline & & 13.0 & 1.7 \\
\hline & & 12.0 & 1.9 \\
\hline & & 13.0 & 3.8 \\
\hline & & 12.0 & 4.1 \\
\hline & & 13.0 & 4.6 \\
\hline & & \multicolumn{2}{|c|}{$(210 \mathrm{~cm}) \&$} \\
\hline
\end{tabular}

Backpit Seam

\begin{tabular}{cr}
\hline & \\
B & ash\% \\
12.0 & 9.1 \\
11.0 & 8.3 \\
13.0 & 8.3 \\
20.0 & 26.3 \\
12.0 & 4.2 \\
11.0 & 6.7 \\
8.5 & 11.5
\end{tabular}

Summary statistics:

$\mathrm{B}$ mean $=12.4 \mathrm{ppm}$

B std $=3.1 \mathrm{ppm}$

correlation: B-ash

$$
=0.46
$$

sample size 27

W, at the western edge of the Coalfield (Fig. 1)

Lingan, Lingan Colliery (Fig. 1). These two channel samples were taken from different places than those in Table 4.

\& Approximate seam thickness.

Analysis of B by Activation Laboratories Limited, using prompt gamma analysis; detection limit $0.5 \mathrm{ppm}$.

Sampling length within a channel sample is approximately $15 \mathrm{~cm}$.

The reduced correlation matrix: input for the factor analysis

Those concentration levels determined on the ashed coal were recalculated to whole-coal equivalent, proportionate to ash content and placed in the data matrix instead (Table 2) for consistency to relate to the whole coal which facilitated factor fitting and interpretation (see Discussion). From the 31 by 137 data matrix, the symmetrical 31 by 31 Pearson correlation matrix was calculated (not shown) and unit values in the principal diagonal row were replaced by communality estimates (see following). This constitutes the reduced correlation matrix and is the input for the factor computations for which the statistical package SPSS (Nie et al., 1975) was used.

\section{Communality}

It is a fundamental postulate for common factor analysis (Table 1) that the unit variance of a standardized variable be partitioned as given by Eq.1:

$1=$ communality + unique $($ specific + error $)$ variance, Eq.1

where communality is generated by the common factors (Harman, 1965, pp. 14-15) and is defined as variance shared between one variable and the remaining variables in the factor model, Eq.2.

For the coal-geochemical data set, it is unrealistic to assume that the unique variance is zero. Apart from the probable error 
Table 7. Hypothesis of the conceptual coal-sulfur model, Sydney Coalfield, Nova Scotia.

Four conceptual processes: $\mathrm{CP} 1$ to $\mathrm{CP} 4$

CP1 fluvial influx into the peat swamp of clayey sediments containing sulfate and metals; interaction with the process 3 is expected;

an important process for sulfur contribution,

CP2 influx into the coalifying(?) peat of recycled sulfate solutions from the evaporite source for pyrite deposition; mutual dependence (interactions) with the remaining processes is not expected;

probably the main and most important process for sulfur contribution,

CP3 hydrothermal? influx into the coalifying(?) peat of sulfide-mineralizing fluids as differentiated from 1);

probably not an important process for sulfur contribution,

and

CP4 influx of lead-rich fluids into the coalifying(?) peat; interaction with process 1 is a possibility for this otherwise unrelated process;

a very minor process for sulfur contribution.

Lower half of the matrix of conceptual interrelationships amongst CP's

$\begin{array}{cccc} & \mathrm{CP} 1 & \mathrm{CP} 2 & \mathrm{CP} 3 \\ \mathrm{CP} 2 & 0 & & \\ \mathrm{CP} 3 & + & 0 & \\ \mathrm{CP} 4 & 0 & 0 & 0\end{array}$

$+=$ interrelationship $\quad 0=$ no interrelationship

measurements in the variables, a second error source is the particular variable selection that was made, error variance due to specificity of Eq.1. In other words, it is not assumed that the variable selection for this study was made without a mistake vis-à-vis the purpose of this study. The estimation of the proportions of the unique variance components is beyond the scope of the present paper, [but see Harman (1965, p. 90) and the Guttmanian image theory].

From Eq.1, it is intuitive that the amount of an initial communality estimate for a variable is the squared multiple correlation coefficient (Harman, 1965, pp. 89-94). This approach is used, realizing of course that communality estimation is a general problem facing factor analysts (Harman, 1965). It is also intuitive that the number of extracted factors is sensitive to the amount of communality factored into the factor matrix in the first place.

It also follows from Eq. 1 that the factor model consists of the common $\underline{F}$ and unique factors $\underline{U}$ ( $\underline{U}$ is decomposable into specific and error factors), which for the sulfur effect is written as follows:

$\underline{F 1} \underline{F 2} \ldots \underline{F 31} \underline{\underline{U}}$
Coal sulfur $=\mathrm{aF}+\mathrm{aF}+\ldots+\mathrm{aF}+\mathrm{bU}, \quad$ Eq.2

and so on for the remaining 30 effects;

effect <- FLOW OF HYPOTHETICAL INFLUENCES

where coal sulfur is the observation variable or the effect; the a's are coefficients of relative importance of influence $\mathrm{F} 1$.... producing the effect, and $\underline{U}$ is the unique factor decomposable into specific and error factors whose coefficients $b$ represent specific and error variances of a variable (Eqs. 1 and 2). The U's are independent of each other and of the F's (Harman, 1965, p. 16, Eq. 2.22). 


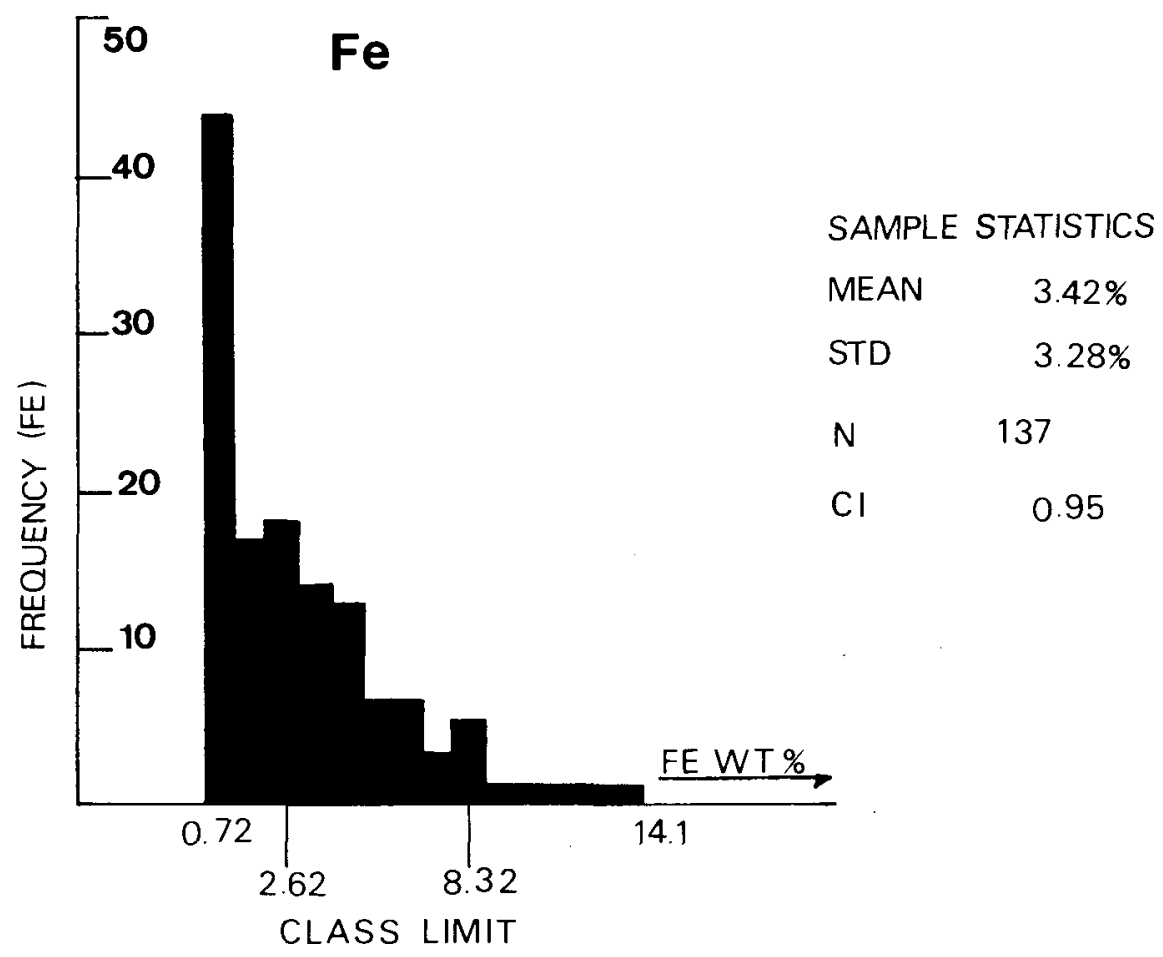

Fig. 3. Frequency distribution of the Fe variable. Symbol explanation as in Figure 2.

\section{Oblique factor rotation}

Oblique rotation invariably yields the desirable simpler factor structure (Cattell and Khanna, 1977, p. 179). Factor simplicity (Harman, 1965, pp. 112-114) refers to the parsimonious explanation whereby an effect is defined by as few factors as possible (in analogy with Ockham's legacy of the scientific method that simpler theories are preferable to more complex ones).

In factor theory, an orthogonal factor matrix, Eq.2, can be correlated, yet the reference axes, the F's, are themselves at right angles and not correlated. Therefore, to assume $a$ priori that factors are uncorrelated is tantamount to preempting the power of the factor analysis inasmuch as such a strategy would deprive the factor analyst of possibly significant information about the data structure itself. The oblique factor model is obtained from obliquely rotating the factor matrix, using rotation for direct oblimin loadings, after Kaiser normalization (Harman, 1965; Nie et al., 1975). The method allows the reference axes to be inclined to each other (being correlated with one another), according to the clustering positions of the variables in common factor space. The degree of obliqueness determines the solution (see below) and to obtain the solution, the obliqueness must, however, be specified by the factor analyst prior to computation.

\section{The Oblique Factor Solution}

The reader is urged to consult Harman's excellent textbook (1965) for enhanced understanding of the advanced concepts involved in modern factor theory.
By the methods of oblique rotation, the factor matrix is decomposed into a factor pattern, structure, and a correlation matrix for a complete solution (Table 1). The factor pattern matrix, which is not used for interpretation, is not shown nor discussed.

\section{The calculated factor matrix}

Under the factor assumptions made, a common sixfactor model (the matrix is not listed) is the accepted solution, after omitting those factors with an associate eigenvalue of less than unity. This is standard practice and based on the assumption that those omitted are difficult to interpret because of insufficient variance explanation (they generate mostly 'noise'; Harman, 1965; Nie et al., 1975). Factoring with iteration was applied until communalities converged to a final value, which happened after 25 iterations, and shown in Table 8 is the excerpt for the sulfur effect. By summing the squared factor loadings across the columns in Table 8 , the estimate of the sulfur communality of 0.9455 is obtained. The factor matrix has the further property that by summing the squared a's across the rows for each factor, explained factor variance is obtained (Table 9). The factors are arranged in decreasing order of importance, as measured in terms of decreasing explained factor variance (Tables 1 and 9).

\section{The calculated correlation and structure matrices}

The most difficult hypothesis to empiracally satisfy in the theory of oblique factor analysis is the degree of obliqueness which must be specified prior to computation. This is 
Table 8. The factor loadings for the sulfur effect.

\begin{tabular}{|c|c|c|c|c|c|c|}
\hline & F1 & $F 2$ & F3 & F4 & F5 & F6 \\
\hline sulfur & 0.6934 & 0.6189 & 0.06511 & -0.2760 & 0.0326 & -0.0079 \\
\hline
\end{tabular}

Final sulfur communality estimate $=0.9455$

Table 9. Common factor statistics.

Factor1 Factor2 Factor3 Factor4 Factor5 Factor6

\begin{tabular}{llllllll}
$\begin{array}{l}\text { Explained common } \\
\text { variance percent: }\end{array}$ & & & & & & & \\
\multicolumn{1}{c}{ Absolute* } & 47.8 & 12.5 & 8.0 & 3.7 & 3.5 & 2.5 & sum $=78.1$ \\
Eigenvalue & 14.81 & 3.86 & 2.49 & 1.16 & 1.10 & 0.78 & sum $=24.18$
\end{tabular}

*Obtained by dividing eigenvalue by number of variables, 31 . The sum $(78.1 \%)$ is the completeness of the sixfactor solution.

particularly difficult, as for the present data it is hypothesized that only some of the conceptual processes are interrelated, others are not (Table 7). The fact that obliqueness selection is under the control of the factor analyst opens the door to simulating factor correlation matrices for studying oblique factor fits. When assuming that factors are orthogonal (cosine angle between paired factors is 90 degrees), the simulated correlation matrix (not shown) showed that not all of the factor correlations were zero as would be expected, if strictly orthogonal. Rather, correlation coefficients as high as 0.44 (angular separation of 63.8 degrees) were observed between F4-F6, and lesser degrees between F1-F4, F1-F6, and F5-F6. On comparison, the correlation pattern is entirely different from that in Table 10, as the negative correlations were not observed. The orthogonal factors could also not be clearly identified with the processes of the conceptual model in Table 7, particularly as no factor could be fitted to the leadrich fluid process 4 , and were therefore rejected. Assuming very high correlations (approximately 0.80 ), no solution was possible as some correlations exceeded unity. So, the degree of factor obliqueness that was finally chosen was of intermediate value (technically delta = zero, Nie et al., 1975) and computed on this assumption were the factor correlation (Table 10) and the factor structure matrices (Table 11). This procedure is in answer to the often-raised objection that the approach to the oblique factor rotation is subjective, and not scientifically objective.

The entries in the factor structure matrix (Table 11) represent the individual correlation between the oblique factor and its effect. The factor structure matrix is not only the key in fitting the factor model to the conceptual coal- sulfur model but it also contains statistically valuable information for use in regression analysis, [refer to Eqs. 4 and 5 and Zodrow (1970)], and it can be used to construct models for each of the remaining 30 effects (e.g., the coal-manganese model with only one underlying influence, Factor5).

\section{Fitting the Oblique factor Model to the Conceptual} MODEL

\section{The oblique factors and their coal-geological identities}

Although the factor solution entails a six-factor model, the complexity for the sulfur effect is only five, Eq.3:

$$
\begin{aligned}
\text { Coal sulfur }= & 0.39 \underline{\text { Factor } 1}+0.94 \underline{\text { Factor } 2}+0.43 \underline{\text { Factor } 3} \\
& +0.32 \underline{\text { Factor } 4}-0.55 \underline{\text { Factor } 6} .
\end{aligned}
$$

where the coefficients are taken from Table 11.

This follows from the structure matrix (Table 11) which shows that the correlation between Factor 5 and the sulfur effect is only -0.09 , or the explained variance is $0.81 \%=$ $(-0.09$ squared) 100 . The point is that Factor 5 hardly influences the sulfur effect and is ineffectual for variance explanation (and need not be fitted to the conceptual coal-sulfur model).

For fitting the oblique Factor 1 in Eq.3, the following explained variance aspects are highlighted: in the six-factor model this is the most important with the largest explained variance of $47.8 \%$ (Table 9); sulfur is moderately defined by an explained variance of $15.21 \%(=0.39$ squared by 100 ; 
Table 10. Lower half of the factor correlation matrix.

\begin{tabular}{llllll}
\hline & Factor1 & Factor2 & Factor3 & Factor4 & Factor5 \\
\hline Factor2 & $0.23(0)$ & & & & \\
Factor3 & $0.30(+)$ & $0.30(0)$ & & & \\
Factor4 & $0.13(0)$ & $0.30(0)$ & $0.01(0)$ & & \\
Factor5 & 0.00 & -0.08 & 0.02 & -0.10 & \\
Factor6 & -0.50 & -0.41 & -0.18 & -0.38 & -0.02 \\
\hline
\end{tabular}

Bracketed values represent conceptual interrelationships (Table 7).

Table 11); in factor theory this is a group factor capable of being decomposed further, were the factor model to be enlarged; the factor correlates considerably (Table 11) with the assumed lithophile elements: $\mathrm{Si}, \mathrm{Mg}, \mathrm{Al}, \mathrm{K}, \mathrm{Ba}, \mathrm{Ti}, \mathrm{Ash}$, $\mathrm{U}, \mathrm{Th}, \mathrm{Sc}$, and $\mathrm{V}$, and the chalcophile element $\mathrm{Cr}$ (in a reducing environment as in a peat swamp, $\mathrm{Cr}$ is likely not lithophile); and of all of the factors it shows the highest correlation with Ash. In effect, the factor probably represents fluvial sedimentary influxes (Hildalgo, 1969; Cheek and Donaldson, 1969; Staub and Cohen, 1979; McCabe, 1987) and is named the Clay Factor. Independent work (Zodrow, 1983) shows that uranium concentration varies directly with clay content and that uranium and thorium concentrations in coal samples are relatable to sedimentary processes (Zodrow et al., 1987), supporting the interpreted identity of the factor. Factor 1 is inferentially linked with the process 1 (Table 12).

In the oblique factor model, the Clay Factor is independent of Factors 2, 4, and 5, and dependent on Factors 3 and 6, with the latter negatively (Table 10).

For Factor 2 , the following require consideration: although it is the second most important of the factor model (explained factor variance is $12.5 \%$, Table 9), it is the most important for the definition of the sulfur variable, explaining $88.36 \%$ variance (Table 11 ); the factor interacts strongly with the chalcophile elements: $\mathrm{Fe}, \mathrm{Cu}$, and $\mathrm{As}$, and moderately so with Ash. The factor probably corresponds to the conceptual process 2 , which embodies the concept of recycling sulfate-rich solution, and is named Pyrite Factor (Table 12).

The Pyrite Factor correlates with Factors $3, \underline{4}$, and 6 and does not with Factor5 nor with the Clay Factor.

For Factor 3 these explained variances are important: it is the third-most important factor $(8.0 \%$ explained factor variance, Table 9) and only contributes modestly to the definition of the sulfur effect (18.49\%, Table 11); the factor interacts with the chalcophile elements $\mathrm{Se}, \mathrm{Ag}$ and $\mathrm{Be}$. On balance, this factor is difficult to interpret, but could probably be linked with process 3 , as mineralizing fluids (hydrothermal activity - Hawley, 1955, p. 425), or as cold-water solutions being part of the sedimentary influxes. The factor is named Sulfide Factor, Table 12.

The Sulfide Factor is dependent of the Clay and Pyrite Factors and is independent of Factors 4,5 and 6.

Factor 4 shows the following: it is the second-least important factor with $3.7 \%$ explained factor variance (Table 9) and contributes $10.24 \%$ to explaining the sulfur effect (Table 11 ); it shows the highest correlation with the $\mathrm{Pb}$ variable, in the presence of mainly very small correlation with the remaining variables, excepting those of $\mathrm{Ge}, \mathrm{Ba}, \mathrm{Sb}$ and $\mathrm{Sr}$ which are larger. The factor plays a minor part in the factor solution (explained factor variance is $3.7 \%$ ) which is consistent if it represents galena related sulfur variation in the coals. It is named the Galena Factor and inferentially linked with process 4 of the conceptual model (Table 11).

The Galena Factor is independent of the Clay and the Sulfide Factors and Factor 5 , and dependent on the Pyrite Factor and negatively so on Factor6.

Factor6 is the least important factor in the oblique factor model, with $2.5 \%$ explained factor variance (Table 9); it is a negative factor since all correlations with the variables, excepting that of $\mathrm{Mn}$, are negative and its contribution to defining the sulfur effect is $30.25 \%$ explained variance (Table 11 ), in a negative sense. In factor theory, the interpretation is that the sulfur effect is best defined by the increasing absence of the hypothetical influence. The high negative correlations are however with the assumed siderophile elements Co and $\mathrm{Ni}$. What the factor interpretation implies is a general 'dilution' effect, or the question is why statistically the $\mathrm{Ni}, \mathrm{Co}, \mathrm{Cu}$, $\mathrm{V}, \mathrm{Cr}$ coal-phases 'dilute' sulfur and clay and also the ash content in the coals? The factor is most difficult to interpret as it has no counterpart in the conceptual model. With some speculation, it could be inferred that Eactor 6 reflects conditions for low-sulfur deposition, assuming that the factor is real and not a product of the communality manipulation.

In the oblique factor model, Factor6 is negatively correlated with the Clay, Pyrite and the Galena Factors, and independent of the Sulfide Factor and the Factor5. 
Table 11. The factor structure matrix.

\begin{tabular}{|c|c|c|c|c|c|c|c|c|}
\hline & & & Factor 1 & Factor2 & Factor3 & Factor4 & Factor5 & Factor 6 \\
\hline \multirow{30}{*}{ 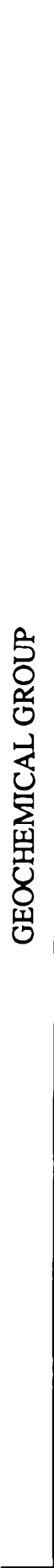 } & \multirow{9}{*}{ 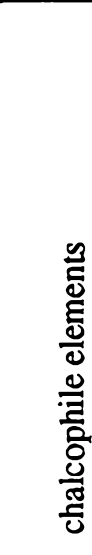 } & $S$ & 0.39 & 0.94 & 0.43 & 0.32 & -0.09 & -0.55 \\
\hline & & $\mathrm{Ag}$ & 0.22 & 0.22 & 0.82 & -0.03 & -0.09 & -0.18 \\
\hline & & As & 0.22 & 0.90 & 0.31 & 0.31 & -0.17 & -0.39 \\
\hline & & $\mathrm{Cr}$ & 0.97 & 0.36 & 0.34 & 0.23 & -0.05 & -0.61 \\
\hline & & $\mathrm{Cu}$ & 0.53 & 0.75 & 0.36 & 0.42 & -0.08 & -0.76 \\
\hline & & $\mathrm{Fe}$ & 0.35 & $\underline{0.94}$ & 0.31 & 0.30 & 0.11 & -0.50 \\
\hline & & $\mathrm{Ge}$ & 0.06 & 0.45 & -0.02 & 0.57 & -0.12 & -0.27 \\
\hline & & $\mathrm{Hg}$ & 0.39 & 0.53 & 0.48 & 0.22 & -0.20 & -0.32 \\
\hline & & $\mathrm{Pb}$ & 0.15 & 0.38 & 0.05 & 0.71 & -0.11 & -0.39 \\
\hline & \multirow{14}{*}{ 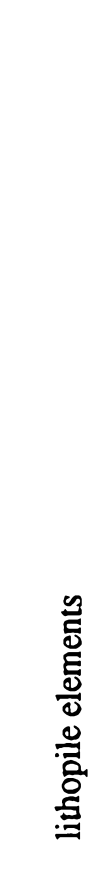 } & $\mathrm{Sb}$ & 0.28 & 0.68 & 0.44 & 0.59 & -0.06 & -0.46 \\
\hline & & $\mathrm{Se}$ & 0.14 & 0.21 & $\underline{0.93}$ & 0.00 & 0.13 & -0.08 \\
\hline & & $\mathrm{Zn}$ & 0.25 & 0.45 & 0.12 & 0.48 & -0.08 & -0.49 \\
\hline & & $\mathrm{Al}$ & $\underline{0.98}$ & 0.21 & 0.23 & 0.18 & -0.02 & -0.56 \\
\hline & & $\mathrm{Ba}$ & 0.87 & 0.30 & 0.25 & 0.59 & -0.02 & -0.61 \\
\hline & & $\mathrm{Be}$ & 0.36 & 0.51 & 0.82 & 0.15 & 0.10 & -0.29 \\
\hline & & $\mathrm{Ca}$ & 0.00 & -0.07 & -0.01 & -0.03 & 0.45 & -0.04 \\
\hline & & $\mathrm{K}$ & 0.94 & 0.24 & 0.25 & 0.05 & 0.01 & -0.50 \\
\hline & & $\mathrm{Mg}$ & 0.88 & 0.31 & 0.41 & -0.03 & 0.22 & -0.45 \\
\hline & & Mn & -0.01 & 0.00 & 0.07 & -0.08 & 0.84 & 0.03 \\
\hline & & $\mathrm{Na}$ & 0.68 & 0.23 & 0.30 & -0.10 & 0.02 & -0.45 \\
\hline & & $\mathrm{Rb}$ & 0.65 & 0.16 & 0.71 & -0.08 & 0.03 & -0.25 \\
\hline & & Sc & 0.96 & 0.29 & 0.32 & 0.26 & -0.07 & -0.57 \\
\hline & & $\mathrm{Si}$ & 0.90 & 0.25 & 0.23 & 0.09 & 0.04 & -0.59 \\
\hline & \multirow{7}{*}{ 苞蒡 } & $\mathrm{Sr}$ & 0.55 & 0.10 & 0.16 & 0.67 & 0.02 & -0.60 \\
\hline & & Th & 0.95 & 0.16 & 0.26 & 0.23 & -0.06 & -0.39 \\
\hline & & $\mathrm{Ti}$ & 0.91 & 0.10 & 0.22 & 0.12 & -0.06 & -0.34 \\
\hline & & $U$ & 0.80 & 0.37 & 0.39 & 0.09 & -0.00 & -0.52 \\
\hline & & V & 0.89 & 0.42 & 0.33 & 0.28 & -0.03 & -0.75 \\
\hline & & Co & 0.54 & 0.38 & 0.22 & 0.34 & 0.05 & -0.95 \\
\hline & & $\mathrm{Ni}$ & 0.50 & 0.47 & 0.20 & 0.42 & 0.01 & -0.97 \\
\hline & & Ash & 0.86 & 0.66 & 0.35 & 0.30 & 0.07 & -0.65 \\
\hline
\end{tabular}


Table 12. Factors fitted to the conceptual processes of the coal-sulfur model, Sydney Coalfield, Nova Scotia.

\section{Factor Model}

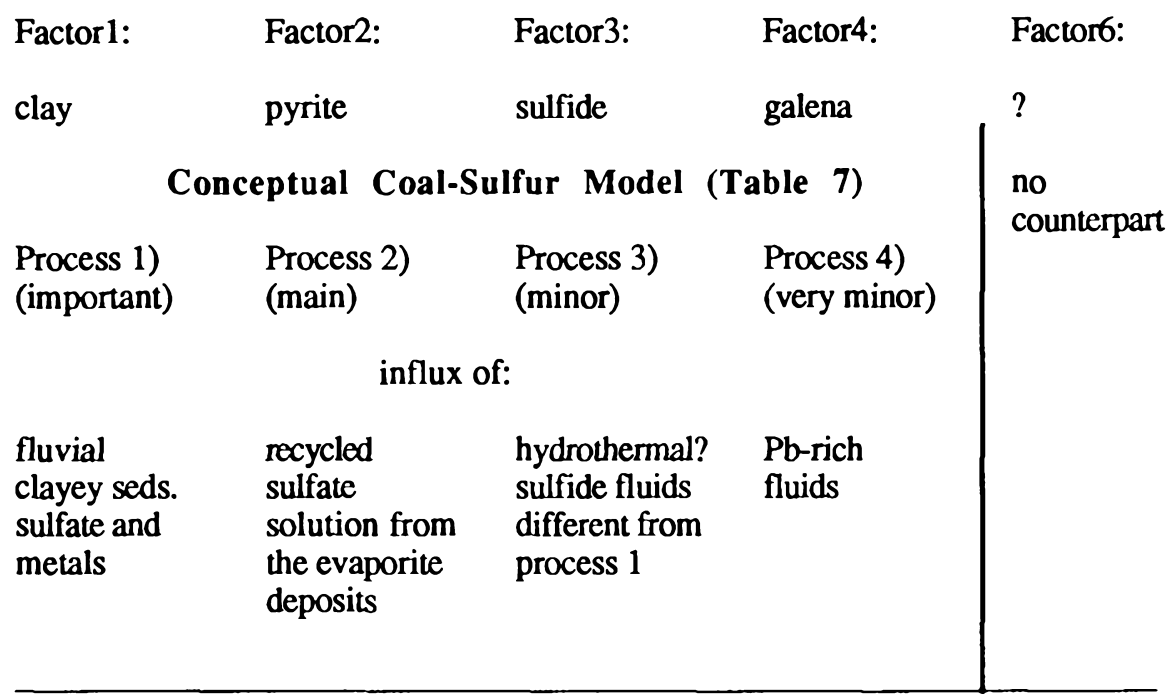

\section{Discussion}

An oblique factor model, based on the reduced correlation matrix in which all concentration levels of the variables were expressed in reference to ashed coal, could not be fitted as the calculated factors could not be matched with the conceptual processes of the coal-sulfur model. Similar results were obtained when variables in the reduced correlation matrix were expressed as in Table 2 (concentration levels for some in reference to ashed coal, for others to whole coal). The choice was then made to convert variables whose concentration levels are determined on ashed coal so that concentration levels of the variables are uniform in reference to whole-coal or equivalent.

In fitting the six-factor model, it is observed that, first, the factor hypothesis regarding the $a$ priori assumption about obliqueness is at variance with the hypothesis about interrelationship of the conceptual processes. In particular, the factor dependence/independence can individually be matched with only four out of the six relationships, on the assumption that a factor correlation of less than 0.3 in Table 10 is difficult to interpret vis-à-vis coal-geological reality and is being regarded as essentially zero in the fitting (paired factors are regarded as being orthogonal). Secondly, the complexity of the sulfur variable is 5 while only 4 conceptual processes are hypothesized. With these shortcomings in mind, the factor model was fitted and is supportive evidence for Birk's (1990) independently-arrived conclusion that Sydney's coal mineralogy is characterized by clay and pyrite.

In terms of statistical measure, the derived six-factor model is $78.1 \%$ complete (Table 9) and the communality estimate for the sulfur-effect equals $94.5 \%$ (Table 8).
Based on the assumptions of six factors which were pumped for maximum variance through communality iteration, the resulting unique variance of $5.5 \%$ (100 - 94.5 communality estimate) does not, of course, represent the error variance for coal sulfur as it would occur in reality. The $5.5 \%$ unexplained variance is acceptably small for a good sulfur definition to possibly forego future investigation. Considering, however, that the incompleteness of the sixfactor model equals $21.9 \%$ (degree to which the six factors cannot reproduce the reduced correlation matrix), the need for clarifying the Factor6 and assumptions made about factor obliqueness, furnish arguments for testing an enlarged conceptual coal-sulfur model in the future. In particular, the reality of Factor6 needs to be investigated, or why it is negative when the option of iteration for communality convergence is used, or when a factor is admitted to a five-factor model in which the option of iteration for communality convergence was not exercised. Further, the temporal relationships amongst the processes require resolution for a better factor fit and criteria are required for epi- and syngenetic pyrite recognition and for clarifying the factor correlations of the Galena Factor. Suggested in this regard is isotopic sulfur analysis and radiometric lead dating (Chow and Earl, 1970; Smith and Batts, 1974).

The question of what additional processes to consider for future inclusion in the conceptual model can in part be answered through the relationship that exists between factor and regression analysis (Harman, 1965). From Table 11, the five best predictor variables, which are underlined, can be selected on the basis of the highest correlation with the factor (Zodrow, 1970) to obtain the coal-sulfur regression model, Eq.4: 
coal sulfur $=f(\mathrm{Al}, \mathrm{Fe}, \mathrm{Se}, \mathrm{Pb}, \mathrm{Ni})$,

Eq.4

with the calculated regression equation in Eq.5:

Sulfur $=0.467+0.16 \mathrm{Al}+1.08 \mathrm{Fe}+0.098 \mathrm{Se}-0.002 \mathrm{~Pb}+0.02 \mathrm{Ni}$

$\left(\begin{array}{lllllll}1.71 & 0.229 & 0.17 & 0.06 & 0.027 & 0.002 & 0.009\end{array}\right)$,

Eq.5

Explained regression variance: $84.8 \%$, where the bracketed values represent the error estimate and can be interpreted as standard deviation.

If the sulfur data is partitioned on the hypotheses:

(1) that if sulfur in one of the 137 samples is larger than $2 \%$ (high sulfur coal), organic sulfur is assumed proportionately less than $1 \%$, and

(2) that if a sulfur sample is below $2 \%$ (low sulfur coal), no pyritic sulfur is assumed only organic sulfur, the results of simulating Eq.5 indicates that the standard deviation of the estimate $(+1.71)$ in Eq.5 is reduced to +1.61 . The statistical result is interpreted as being consistent with the coal-sulfur discussion that an organic sulfur process ought to be recognized for the future conceptual model. Of interest would also be data on the variations of roof and floor strata permeabilities, to introduce into the conceptual model processes that address pyrite deposition at site. Of further interest is information on how some metals are partitioned between the organic and the inorganic phases in coal to be able to introduce concepts of geochemical processes in the conceptual model. With these additions, a sophisticated coalsulfur model could be expected.

\section{Conclusion}

Based on the composite coal-geological hypotheses and the complex factor analytical assumptions, the oblique sixfactor model is arrived at. The coal mineralogy, which in the Sydney Coalfield is predominantly clay and pyrite, can be adequately explained by the influences of the hypothetical factors which are inferentially linked with general sedimentary and geochemical processes. What awaits resolution is the question of the (1) reality of the fifth factor, (2) temporal order of the factor influences and the differential time relation of multistage pyrite formation, and (3) that of the degree of factor obliqueness and refinement of interrelationships for the conceptual coal-sulfur model. In effect, addition of these variables would result in a refined coal-sulfur model.

This in effect is the first attempt of studying variability of sulfur in the coals in the Sydney Coalfield by methods of factor analysis and furnishing empirical criteria for comparison with other Pennsylvanian coalfields.

\section{ACKNOWLEDGEMENTS}

I gratefully acknowledge the financial support received from the National Science and Engineering Research Coun- cil of Canada. Reviewers of Atlantic Geology, Drs. M. Gibling, M. Labonté, and P.K. Mukhopadhyay, are gratefully acknowledged for focusing attention on methodology and presentation to improve the manuscript. I thank Andrew Beaton for use of the sulfur-form data (Table 3 ).

Beaton, A.P. 1986. Stratigraphic sulfur form distribution in the Harbour Seam, Sydney, N.S. Unpublished B.Sc. thesis, St. Francis Xavier University, Antigonish, Nova Scotia, Canada, 63 p. plus appendices.

Berry, L.G., Mason, B., and Dietrich, R.V. 1983. Mineralogy. Second Edition. W.H. Freeman and Company.

BIRK, D. 1990. Quantitative coal mineralogy of the Sydney Coalfield, Nova Scotia, Canada, by scanning electron microscopy, computerized image analysis, and energy-dispersive $\mathrm{X}$-ray spectrometry. Canadian Journal of Earth Sciences, 27. pp. 163-179.

Casagrande, D.J. 1987. Sulphur in peat and coal. In Coal and Coal-bearing Strata: Recent Advances. Edited by A.C. Scott. Geological Society Special Publication No. 32, pp. 87-105.

Casagrande, D.J. and Siefert, K. 1977. Origins of sulfur in coal: The importance of the ester sulfate content in peat. Science, 181, pp. 675-676.

Cattell, R.B. and Khanna, D.K. 1977. Principles and procedures for unique rotation in factor analysis. In Statistical Methods for Digital Computers. Edited by K. Enslein, A. Ralston and H.S. Wilf. Wiley, New York, pp. 166-202.

Cheek, R. and Donaldson, A. 1969. Sulfur facies of the Upper Freeport Coal of northwestern Preston County, West Virginia. In Some Appalachian Coals and Carbonates: Models of Ancient Shallow-water Deposition. Edited by A.C. Donaldson. Preconvention GSA Field trip, November 1969, Morgantown, pp. 279-307.

Chow, T.J. and EARL, J.L. 1970. Lead and uranium in Pennsylvanian anthracite. Chemical Geology, 6, pp. 43-49.

Foroeron, S., Ma CKenzie, B., and MacPherson, K. 1986. The effects of geological features on coal mining, Sydney Coalfield, Nova Scotia. Bulletin of the Canadian Institute of Mining and Metallury, 79, pp. 79-87.

Gibling, M.R., Zentilli, M., Mahony, H., and McCready, R.G.L. 1989. Sulphur in Pennsylvanian coals of Atlantic Canada: geologic and isotopic evidence for a bedrock evaporite source. International Journal of Coal Geology, 11, pp. 81-104.

Hacquebard, P.A. and Donaldson, J.R. 1969. Carboniferous coal deposition associated with flood plain and limnic environments of Nova Scotia. Geological Society of America, Special Paper 114, pp. 143-191.

Haites, T.B. 1951. Some geological aspects of the Sydney Coalfield with reference to their influence on mining operations. The Canadian Mining and Metallurgical Bulletin, 44, pp. 329-339.

HARMAN, H.H. 1965. Modern factor analysis. Fourth impression. The University of Chicago Press.

Hawley, J.E. 1955. Spectrographic study of some Nova Scotia coals. Transactions of the Canadian Institute of Mining and Metallurgy, 58, pp. 412-426.

Hidalgo, R.V. 1969. Sulfur-clay mineral fractions in coal. In Some Appalachian Coals and Carbonates: Models of Ancient Shallow-water Deposition. Edited by A.C. Donaldson. Pre- 
convention GSA Field trip, November 1969, Morgantown, pp. 309-320.

KeIth, M.L. and Degens, E.T. 1959. Geochemical indicators of marine and fresh-water sediments. In Researches in Geochemistry. Edited by P.H. Abelson, pp. 38-61.

Kendall, M.G. 1965. A course in multivariate analysis. Charles Griffin and Company.

Krejci-Graf, K. 1984. Uber die Elemente in Kohlen. Erdöl und Kohle-Erdgas-Petrochemie vereinigt mit Brennstoff-Chemie, Bd., 37, pp. $451-457$.

MCCABE, P. 1987. Facies studies of coal and coal-bearing strata. In Coal and Coal-bearing Strata: Recent Advances. Edited by A.C. Scott. Geological Society Special Publication 32, pp. 51-66.

MulaIK, S.T. 1972. The foundation of factor analysis. McGrawHill.

Newman, W.R. 1935. Microscopic features of the Phalen Seam, Sydney Coalfield, N.S. Canadian Journal of Research, 12, pp. 533-553.

Nie, N.H., Hull, C.H., Jenkins, J.G., Steinbrenner, K., and BENT, D.H. 1975. Statistical package for the social sciences. Second Edition. McGraw-Hill.

REYMENT, R.A. 1971. Multivariate normality in morphometric analysis. Mathematical Geology, 3, pp. 357-368.

SANDEMAN, M.R. 1979. Thermal and epithermal neutron activation analysis of Nova Scotia raw and washed coals. Unpublished M.Sc. thesis, Dalhousie University, Halifax, Nova Scotia, Canada, p. 122.

Sмiтh, J.W. and BATTS, B.D. 1974. The distribution and isotopic composition of sulfur in coal. Geochimica et Cosmochimica Acta, 38, pp. 121-133.

SPEARS, D.A. 1987. Mineral matter in coals, with special reference to the Pennine Coalfields. In Coal and Coal-bearing Strata: Recent Advances. Edited by A.C. Scott. Geological Society Special Publication No. 32, pp. 171-185.

Spiro, C.L., Wong, J., Lytle, F.W., Greegor, R.B., Maylotte, D.H., and LAMson, S.H. 1984. X-ray absorption spectroscopic investigation of sulfur sites in coal: organic sulfur identification. Science, 226, pp. 48-50.

StaUb, J.R. and Coнen, A.D. 1979. The Snuggedy swamp of South Carolina: A back-barrier estuarine coal-forming envi- ronment. Journal of Sedimentary Petrology, 49, pp. 133-144. Thibaudeau, S.A. 1987. Paleontological evidence for marine incursion in the Sydney Basin deposits (Carboniferous, Nova Scotia). Program with Abstracts, Canadian Paleontology and Biostratigraphy Seminar, London, Ontario, September 25 27, pp. 8-9.

VASEY, G.M. AND Zodrow, E.L. 1983. Environmental and correlative significance of a non-marine algal limestone (Westphalian D), Sydney Coalfield, Cape Breton Island, Nova Scotia. Maritime Sediments and Atlantic Geology, 19, pp. 1-10.

ZoDrow, E.L. 1970. Factor analyses and magnetite formation and distribution in the Smallwood Mine. Society of Mining Engineers, AIME, Transactions, 247, pp. 61-69.

1983. Some geochemical aspects of sedimentary rocks in proximity of coals, Sydney Coalfield (Upper Carboniferous), Cape Breton Island, Nova Scotia, Canada. Intemational Journal of Coal Geology, 2, pp. 299-320.

- 1987. Geochemical trends in whole-seam coal channel samples from the Sydney coalfield (Upper Carboniferous), Nova Scotia, Canada. Maritime Sediments and Atlantic Geology, 23, pp. 141-150.

Zodrow, E.L. and CleAL, C.J. 1985. Phyto- and chronostratigraphical correlations between the late Pennsylvanian Morien Group (Sydney, Nova Scotia) and the Silesian Pennant Measures (south Wales). Canadian Journal of Earth Sciences, 22, pp. 1465-1473.

Zodrow, E.L. and MACCANDLISH, K. 1978. Hydrated sulfates in the Sydney Coalfield, Cape Breton, Nova Scotia. Canadian Mineralogist, 16, pp. 17-22.

Zodrow, E.L., BanerJee, S.K., and Jessome, D.R. 1987. Uranium content and distribution in whole-coal samples, Sydney Coalfield (Upper Carboniferous), Nova Scotia, Canada. International Journal of Coal Geology, 8, pp. 299-303.

Zodrow, E.L., Beaton, A.P., and SMith, G. 1989. Note on a find of a crossopterygian head (Pisces), upper Westphalian D, Sydney Coalfield, Nova Scotia, Canada. Atlantic Geology, 25, pp. 125-127.

Zubovic, P. 1966. Physicochemical properties of certain minor elements as controlling factors in their distribution in coal. In Coal Science. American Chemical Society, Advances in Chemistry, 55, pp. 221-231. 